\title{
FACTORS IN THE ADOPTION OF BEEF CATTLE ARTIFICIAL INSEMINATION (AI) TECHNOLOGY IN BREBES REGENCY
}

\author{
Faktor - Faktor Adopsi Teknologi Inseminasi Buatan (IB) Sapi Potong di Kabupaten \\ Brebes
}

Lucie Setiana $^{1, *}$, Dadang Mulyadi Saleh ${ }^{1)}$, Aras Prasetiyo Nugroho ${ }^{1)}$, and Dayu Lingga Lana ${ }^{2}$

${ }^{1}$ Faculty of Animal Science, Jenderal Soedirman University, Purwokerto 53122, Indonesia

${ }^{2}$ Department of Livestock \& Animal Health Brebes Regency, Brebes 52214, Indonesia

${ }^{*}$ E-mail: luciesetiana23@gmail.com

\begin{abstract}
Efforts to increase beef cattle population and genetic in Brebes Regency can be done by using artificial insemination (AI) technology approach.Therefore this study aims to determine the factors that influence the ability of beef cattle farmers in adopting artificial insemination technology (AI) in Brebes Regency. Survey method was applied to observe beef cattle and farmers. Sampling technique used Slovin formula with $90 \%$ significant rate to observe variables, namely the ability of farmers to adopt AI technology $(\mathrm{Y})$; social factors $\left(\mathrm{X}_{1}\right)$ consisting of age $\left(\mathrm{X}_{1.1}\right)$, educational background $\left(\mathrm{X}_{1.2}\right)$, farming experience $\left(\mathrm{X}_{1.3}\right)$, herd size $\left(\mathrm{X}_{1.4}\right)$; technical factors consisting of $\mathrm{S} / \mathrm{C}\left(\mathrm{X}_{2.1}\right)$ and oestrous detection $\left(\mathrm{X}_{2.2}\right)$; and economic factor is $\mathrm{AI}$ costs $\left(\mathrm{X}_{3}\right)$. The research data obtained were analysed using descriptive analysis and correlation. The results showed that adoption of artificial insemination in beef cattle in Brebes Regency had a negative correlation with age $\left(\mathrm{X}_{1.1}\right)$ ( $\left.\mathrm{rs}=-0.498\right)$, did not correlate with educational background $\left(\mathrm{X}_{1.2}\right)(\mathrm{rs}=0.221)$, farming experience $\left(\mathrm{rs}=\mathrm{X}_{1.3}\right)(\mathrm{rs}=-0.056)$, and the herd size $\left(\mathrm{X}_{1.4}\right)(\mathrm{rs}=0.094)$ as social factors; does not correlate with the value of $\mathrm{S} / \mathrm{C}\left(\mathrm{X}_{2.1}\right)(\mathrm{rs}=0.203)$ and estrous detection $\left(\mathrm{X}_{2.2}\right)(\mathrm{rs}=0.259)$ as technical factors; and negatively correlate.ed with AI cost $\left(\mathrm{X}_{3}\right)(\mathrm{rs}=-0,661)$ as an economic factor. From the results of the study, it can be concluded that the adoption of artificial insemination in beef cattle in Brebes Regency is influenced by social and economic factors, especially from the age factor and AI cost factor that is less supportive.
\end{abstract}

ABSTRACT

Keywords: Artificial Insemination, Beef Cattle Farmers, Economic Factor, Social Factors, Technical Factors

\section{ABSTRAK}

Upaya peningkatkan populasi dan genetik sapi potong di kabupaten brebes dapat dilakukan dengan pendekatan teknologi inseminasi buatan (IB). Oleh karena itu penelitian ini dilakukan dengan tujuan untuk mengetahui faktorfaktor yang mempengaruhi kemampuan peternak sapi potong dalam mengadopsi teknologi inseminasi buatan (IB) di Kabupaten Brebes. Metode survey diterapkan untuk mendapatkan data dan teknik pengambilan sampel menggunakan rumus Slovin dengan tingkat signifikansi $90 \%$ untuk mengamati variabel, yaitu kemampuan peternak untuk mengadopsi teknologi IB $(Y)$; faktor sosial $\left(X_{1}\right)$ terdiri dari usia $\left(X_{1.1}\right)$, latar belakang pendidikan $\left(X_{1.2}\right)$, pengalaman beternak $\left(X_{1.3}\right)$, jumlah kepemilikan ternak $\left(X_{1.4}\right)$; faktor teknis terdiri dari nilai $S / C\left(X_{2.1}\right)$ dan deteksi estrus $\left(X_{2.2}\right)$; dan faktor ekonomi adalah biaya operasional $\left(X_{3}\right)$. Data Penelitian yang diperoleh dianalisis menggunakan analisis deskriptif dan korelasi. Hasil penelitian menunjukkan bahwa adopsi inseminasi buatan pada sapi potong di Kapubaten Brebes mempunyai korelasi negatif dengan usia $\left(X_{1.1}\right)(r s=-0,498)$, tidak berkorelasi dengan latar belakang pendidikan $\left(X_{1.2}\right)(r s=0,221)$, pengalaman beternak $\left(X_{1.3}\right)\left(r_{s}=-0,056\right)$, dan jumlah kepemilikan ternak $\left(X_{1.4}\right)(r s=0,094)$ sebagai faktor sosial; tidak berkorelasi dengan nilai $S / C\left(X_{2.1}\right)(r s=0,203)$ dan deteksi estrus $\left(X_{2.2}\right)(r s=0,259)$ sebagai faktor teknis; dan berkorelasi negatif dengan biaya operasional $\left(X_{3}\right)(r s=-0.661)$ sebagai faktor ekonomi. Dari penelitian dapat disimpulkan bahwa adopsi inseminasi buatan pada sapi potong di Kabupaten Brebes di pengaruhi oleh faktor sosial dan ekonomi, terutama dari faktor usia dan faktor biaya operasional yang kurang mendukung.

Kata Kunci: Inseminasi Buatan, Peternak Sapi Potong, Faktor Ekonomi, Faktor Sosial, Faktor Teknik

Content from this work may be used under the terms of theCreative Commons Atribusi-BerbagiSerupa 4.0 International. Any further distributionof this work must maintain attribution to the author(s) and the title of the work, journal citation and DOI.

Published under Department of Communication and Community Development Science, IPB University

ISSN : 1858-2664 | E-ISSN : 2442-4110 


\section{INTRODUCTION}

Brebes has high availability of feed commodity and ruminants. According to Indonesia Statistics (2013), agriculture waste and grass reach 289,309 ST while ruminant population just 21,009 ST. The facts showed Brebes regency has the potency to develop ruminants. Beef cattle population in Brebes are 28,031 consists of $61.37 \%$ bulls and $38.66 \%$ cows (BPS, 2013). A higher bull population made the farmers reluctant to apply artificial insemination (AI) for mating. Report of AI Practice in Brebes in 2013 stated that AI recipients were 2,026 doses or $18.7 \%$ of the total cows. Besides farmers ability to adopt technology, the contributing factors to the low percentage of AI adoption are poor service system, human resource i.e. inseminator and farmers characteristics, and the remote area (Bansal et al., 2019). Farmer's acceptance of technology innovation is closely relative to an individual background (Rathod et al., 2017). The average of the rate of AI adoption is 2.39 years (Ma'sum et al., 2013). Artificial insemination (AI) is, in fact, a common technology; however, farmers met many obstacles such as scarce inseminator (14 people) that inseminated only 200-225 cattle per month. In addition, Artificial Insemination Service Unit (SPIB) only consisted of 7 units of AI service (ULIB). The limited facility and funding adversely obstruct the success of AI (Department of livestock and animal health, 2015).

The success of AI adoption was influenced by internal and external factors. Internal factor consists of technical, social and economic aspects in each farmer. While, external factors consist of technology limitation, inseminator competence, and farmer's location. Each of these factors can be identified using correlations with very weak, weak, medium, and strong strengths for the adoption of AI technology. If these factors can be identified, it will be a good reference for the government to help make policies that support the adoption of artificial insemination in the Brebes district. Therefore, this study was aimed to conduct further investigation on AI technology adoption to improve the ability of beef cattle farmers in Brebes for a sustainable breeding program.

\section{METHODS}

\section{The Site Research}

The research located in Brebes, which has been determined as the distribution of the Jabres Cattle (Minister of Agriculture Decree No. 2842/Kpts/LB.430/8/2012, 2012), Central Java, Indonesia.

\section{The Research Variables}

Research variables consisted of $\mathrm{Y}$ : the ability of farmers to adopt $\mathrm{AI}$ technology, $\mathrm{X}_{1}$ : social factors $\left(\mathrm{X}_{1.1}\right.$ : age, $\mathrm{X}_{1.2}$ : education, $\mathrm{X}_{1.3}$ : farming experience, $\mathrm{X}_{1.4}$ : herd size $), \mathrm{X}_{2}$ : technical factors $\left(\mathrm{X}_{2.1}\right.$ : Service per Conception (S/C), $\mathrm{X}_{2.2}$ : oestrous detection), $\mathrm{X}_{3}$ : economic factor (AI cost).

\section{The Research method}

Survey method was applied to observe 28 beef cattle farmers in 6 selected districts in the Brebes regency; large population: Bantarkawung (11 respondent) and Paguyangan (10 respondent); medium population: Tonjong (4 respondent); and small population: Simrapog (1 respondent), Bulakamba (1 respondent), and Songgom (1 respondent). The sampling technique used Slovin formula with $90 \%$ significant rate $(\mathrm{d}=0.1) . \backslash$

\section{The Data Analysis}

Primary data obtained from the interview process directly to farmers. Secondary data were collected from the Department of Livestock and Animal Health Brebes, Indonesian Statistics (BPS) 2013 and literature review. Primary data consists of direct interviews with farmers, such as education, farming experience, herd size, Service per Conception, oestrous detection, and AI cost, while secondary date such as area agriculture and animal, data of inseminator. Spearman's rank correlation was used to measure the association of free variables $(\mathrm{X})$ and bound variable namely AI adoption rate (Y). 


\section{RESULTS AND DISCUSSIONS}

\section{Overview of Brebes Regency}

The majority of Brebes populations (40.67\%) were agriculture farmworkers. Most of the land $(63,343 \mathrm{ha})$ was rice plantation. Many labourers raised cattle at home for saving and additional income. Beef cattle population in Brebes was relatively large. It was supported by natural resources in the form of agricultural waste for feed. The carrying capacity of Brebes is 13.37 or exceeding 1 which indicates a potency of ruminant development to provide cattle products for local consumption. Among various attempts the government has made to meet animal product demand is importing from other countries. Another alternative was by increasing the domestic population that can be supported by implementing cattle reproduction technology.

\section{Correlation Analysis of Social, Economic and Technical Factors to AI Adoption Rate}

Personal decision making is influenced by varied factors. Some factors that might contribute to AI adoption rate of beef cattle farmers in sub-districts of Brebes regency were social factors included age, education, farming experience and herd size; technical factors included $\mathrm{S} / \mathrm{C}$ and oestrous detection, and economic factor included AI cost. Analysis of the correlation between three factors and innovation adoption of beef cattle farmers is presented in Table 1.

Table 1 Correlation between factors of social, technical, and economic and AI technology adoption of beef cattle farmers

\begin{tabular}{|c|c|c|c|c|c|}
\hline $\mathbf{V a}$ & iable X & Variable Y & $\begin{array}{l}\text { Speraman's } \\
\text { Correlation }\end{array}$ & $\begin{array}{l}\text { Correlation } \\
\text { Strength }\end{array}$ & Note \\
\hline & Age $\left(X_{1.1}\right)$ & & -0.498 & moderate & significant $(*)$ \\
\hline Social & $\begin{array}{l}\text { Educational } \\
\text { background } \\
\left(\mathrm{X}_{1.2}\right)\end{array}$ & & 0.221 & weak & non-significant \\
\hline $\begin{array}{l}\text { Factors } \\
\left(\mathrm{X}_{1}\right)\end{array}$ & $\begin{array}{l}\text { Farming } \\
\text { experience } \\
\left(\mathrm{X}_{1.3}\right)\end{array}$ & AI Technology & -0.056 & very weak & non-significant \\
\hline & $\begin{array}{l}\text { Herd size }(X \\
1.4)\end{array}$ & Adoption (Y) & 0.094 & very weak & non-significant \\
\hline Technical & $\mathrm{S} / \mathrm{C}\left(\mathrm{X}_{2.1}\right)$ & & 0.203 & weak & non-significant \\
\hline $\begin{array}{c}\text { Factors } \\
\left(\mathrm{X}_{2}\right)\end{array}$ & $\begin{array}{l}\text { Oestrous } \\
\text { detection }\left(\mathrm{X}_{2.2}\right)\end{array}$ & & 0.259 & weak & non-significant \\
\hline $\begin{array}{c}\text { Economic } \\
\text { Factor }\left(\mathrm{X}_{3}\right)\end{array}$ & $\mathrm{AI} \operatorname{cost}\left(\mathrm{X}_{3}\right)$ & & -0.661 & strong & $\begin{array}{l}\text { very significant } \\
\qquad(* *)\end{array}$ \\
\hline
\end{tabular}

Source: research data's

\section{Social Factors}

Table 1 showed that the correlation of social aspects in terms of the characteristics of beef cattle farmers and AI innovation adoption is very weak on farming experience and herd size. Education has a weak correlation with the adoption rate, while age shows moderate correlation. The age of the farmers determines the breeding experience. The farmer who already has a successful AI experience will certainly choose AI adoption to improve the capacity of beef cattle. Other than that, young people will be more open and courageous to try to apply technology to improve the productivity of their beef cattle (Prawira \& Sutrisna, 2015).

\section{Farmers' Age}

Age significantly affected AI adoption decision making. It had a moderate correlation ( $\mathrm{rs}=-$ 0,498 ) with AI adoption in Brebes with a negative score. A negative score of Spearman's correlation 
rank showed that age was not linear with AI application; however, farmers' age was strongly correlated with learning motivation. The aged farmers had limited energy to manage the farming and less motivated to develop farming because it was regarded as a side job. In contrast, young farmers were enthusiastic to change and adopt technology because the more profit they gained, the more motivated they became to venture in beef cattle farming. Individual learning capacity generally escalates up to 20 years old and peaks at 55 years. Age is one of the main factors of learning efficiency because it affects an individual interest in certain professions. It has been in line with previous studies, that age is among the many aspects that determine individual enthusiasm to learn (Akin \& Kara, 2019). Age was correlated with education (Mazumder \& Hoque, 2018). The aged farmers with weak education would be difficult to adopt technology, particularly a complex and highrisk technology such as AI.

\section{Education background}

Table 1 showed that the education background of beef cattle farmers is not significant on innovation adoption in Brebes, in fact indicating weak correlation $(\mathrm{rs}=0.221)$. It was because most farmers had limited education; some did not pass primary school, barely passed primary school (6 years), and passed middle school (9 years). A positive score in Spearman's correlation rank indicates that high education is linear with AI technology adoption.

Farmers who have a low level of education, only graduated from primary or middle school were limited in understanding technology (Bachev et al., 2017). Nevertheless, some farmers in Brebes perceived and were aware of AI, and it was evidenced by the response to AI. The majority of farmers in Brebes were resistant to innovations or only receptive to particular innovations that were assumed to impose a direct change to the farmer. The attitude of self-contained with the existing cattle farming has restricted the farmers from accepting new technology. It has been in line with previous studies, that education did not affect the acceptability of AI adoption in Ciamis regency (Sirajuddin et al., 2018). Farmers' education level affected their perspective, learning ability and intellectuality (Yunasaf, 2012). Formal or informal education would help farmers widen their knowledge and horizon to be more responsive to innovation that might be beneficial to their farming. Nevertheless, education was not an absolute aspect that limited farmers to have forward-thinking. Although classified as low educated, some farmers were to implemented AI adoption. Informal education can informal learning can be done by counselling with simple print media such as booklet. Booklet media can be used as information media for artificial insemination so that it has a positive impact on farmers to increase livestock production in an area. But, one-on-one method is the best used by the extension is the conduct of seminar or conferences (Declaro-Ruedas \& Bais, 2019). A good method for counselling were education, dissemination, consultation, coaching, and evaluation (Edwina et al., 2019).

\section{Farming Experience}

The farming experience was weakly correlated ( $\mathrm{rs}=-0.056)$ with $\mathrm{AI}$ adoption in Brebes with a negative score. It showed that farming experience did not significantly affect AI decision making, while the negative score indicated that farming experience was not linear with AI implementation. This was presumably because according to the experience of farmers, the result of mated naturally more satisfactory than AI. Beef cattle farming was considered a side job due to limited time allocation. The farming experience was not correlated with the size of cattle kept. This happens because farmers will soon sell their cattle when the selling price had well. Other than that, urgent basic needs had prompted the farmers to sell the cattle. It was in contrast previous study, that farming experience would provide help to problem-solving and decision-making when facing problem in the venture (Giampaoli et al., 2017).

\section{Herd size}

Table 1 shows that size was not significant to the decision of innovation adoption in Brebes $(r s=0.094)$ indicated by the constant number of cattle kept $(1-3 \mathrm{ST})$. The result of this research 
showed that farmers had no intention to expand the farming because they refused to take a bigger risk for AI cost without optimum result. Accordingly, herd size was crucial to help increase income and meet basic needs because the bigger the farming scale, the more income received. Farmers in Brebes were facing capital limit since the price of adult cattle exceeded 20 million rupiahs. The capital was essential to expand beef cattle farming but it had to be supported by both human and natural resources. Farmers' reluctance to increase herd size was the limited technical aspect in terms of managerial skill to manage large-scale farming (Wiseman et al., 2019).

\section{Technical factors}

Technical aspects observed in this study were $\mathrm{S} / \mathrm{C}$ value and oestrous detection. Table 1 showed that technical aspects were weakly correlated with AI innovation adoption which was evidenced from $0.203 \mathrm{~S} / \mathrm{C}$ and 0.259 oestrous detections. Accordingly, technical aspects were not significant to decide to adopt AI in Brebes. This had through to have occurred because AI adoption was no better than natural.

\section{Service per Conception (S/C)}

$\mathrm{S} / \mathrm{C}$ value had a weak correlation with AI adoption in Brebes. This matter had presumed to make cattle pregnant, a farmer must do AI more than once. Its cause farmers suffered from the loss of time, energy and money. High S/C value will increase production costs, thus reducing the profit of farmers (Table 2).

Table 2 Description of service per conception value farmer's responden

\begin{tabular}{ccc}
\hline Frequency of AI & Respondent & Precentage (\%) \\
\hline 1 & 21 & 75 \\
2 & 5 & 17.86 \\
3 & 2 & 7.14 \\
$>3$ & 0 & 0 \\
\hline Amount & 28 & 100 \\
\hline
\end{tabular}

The contributing factors of $\mathrm{S} / \mathrm{C}$ value were environment (cage and temperature), semen, thawing, and transportation (Setiawan, 2018). The more time needed to transport semen to the location of insemination, the lower was semen fertility and therefore the higher $\mathrm{S} / \mathrm{C}$ value. Weak correlation between $\mathrm{S} / \mathrm{C}$ and $\mathrm{AI}$ innovation adoption was due to weak oestrous detection. Both factors were interconnected and high $\mathrm{S} / \mathrm{C}$ value was because farmers of inseminators were slow to detect oestrous and the improper time to conduct $\mathrm{AI}$. Besides estrous detection, high $\mathrm{S} / \mathrm{C}$ value was due to (1) silent heat, (2) reproductive problems, (3) age at first calving, and (4) calving interval (Bansal et al., 2019).

\section{Oestrous detection}

Table 1 shows that farmer's ability oestrous detection in beef cattle was not significant on the decision to AI adoption in Brebes. Although almost half of the farmers had the ability to detect oestrous (Table 3). One of the knowledge that must be possessed by farmers in AI adoption is oestrous detection (Ma'sum et al., 2012). Besides the human factor, cattle fertility had a significant contribution. Exotic breed tended to have weak fertility, so natural mating with bull would result in better insemination. Reproductive efficiency was a potency that supported the change process to prompt innovation adoption. Farmer's perspective was the driving force to change. The current beef cattle farmers in Brebes held on to the tradition of natural mating and only accepted innovation that imposed direct change. They would be difficult to embrace change but might still open to new ideas with prolonged time and patience. An extension agent had to earn a farmer's trust first about AI technology to prevent rejection from them. In some cases, farmers empowerment started by introducing the simplest innovation that still correlated with the existing farming tradition, and farmers were not obliged to comply. Another strategy was by involving the third party as a mediator, for example, educational institutions and government agencies (Abdullah \& Sharun, 2018). 
Table 3 Ability of farmer's responden to detect estous

\begin{tabular}{ccc}
\hline Category & Responden & Presentase (\%) \\
\hline Good & 16 & $57.14 \%$ \\
Enough & 8 & $28.57 \%$ \\
Less & 4 & $14.29 \%$ \\
\hline amount & 28 & $100 \%$
\end{tabular}

Source: research data's

\section{Economic factor (AI cost)}

Economic aspects (AI cost) and AI innovation adoption in Brebes had strong correlation but negative score $(\mathrm{rs}=-0.661)$. It indicated that higher AI cost lower adoption behaviour. The result showed that AI cost for beef cattle in Brebes was relatively expensive, no less than Rp 50.000,00 (Table 4). According to (Monintja et al., 2015), AI cost for 91 Ongole breeds in Tompaso Barat was $\mathrm{Rp} 4.600 .000,00$ or $\pm \mathrm{Rp} 50.500,00$ each. It was supported by (Sugiarto et al., 2019) that the average AI cost for beef cattle in Banjarnegara was Rp 50.000,00. Bahar (2017) reported that AI cost was varied according to the region and significantly affected by the distance from the inseminator location. In addition, AI cost was affected by the availability of breed and liquid $\mathrm{N}_{2}$. If the local AI Centre was nonexistent in the region, semen had to be imported from other region or AI centre (BBIB), therefore imposing more cost. (Bahar et al., 2017) argued that the larger the venture, the faster is technology adoption because of a more stable economy, while small-scale farmers generally had marginal living.

Table 4. AI cost for beef cattle in Brebes Regency

\begin{tabular}{ccc}
\hline AI cost (IDR) & Respondent & Precentage (\%) \\
\hline$<50.000$ & 8 & 28.57 \\
$50.000-74.000$ & 4 & 14.29 \\
$75.000-99.000$ & 10 & 35.71 \\
$100.000-124.000$ & 6 & 21.43 \\
\hline Amount & 28 & 100 \\
\hline
\end{tabular}

Source: research data's (There is no restriction on AI fees, voluntary farmer)

Economic power is a significant factor in decision making (Table 4). For example, the availability of funding or farming loan will affect farmers' decision to adopt technology innovation. Furthermore, it is important to investigate the obstacles toward change that includes the past fear due to trust issues from disappointment or failure experience, unprepared for change due to some limitations and reluctance to risk-taking and self-contentedness with the current condition (Ingabire et al., 2018).

\section{CONCLUSION}

There is a relationship between socio-economic factors of beef cattle farmers in Brebes Regency with the ability of farmers in adopting AI technology, especially from age and economic factors that are less supportive. While educational background factors, farming experience, service per conception, estrus detection do not correlate with Adoption of AI Technology. From the results of the study, it was suggested to the relevant committee to conduct a counselling process about AI to young farmers and AI post closer to farmers to reduce cost.

\section{ACKNOWLEDGEMENT}

Thanks delivered to Indonesian Statistic (BPS) and Department of Livestock and Animal Health Brebes Regency, Jl. Taman Siswa, Padasugih, Brebes, Central Java.

\section{REFERENCES}

Abdullah, F. A., \& Sharun, M. S. (2018). Level of technology acceptance on Assisted Reproductive Technology (ART) among ruminant farmers in Kelantan, Malaysia. J. Trop. Resour. Sustain. 
Sci, 6, 77-79.

Akin, S., \& Kara, A. (2019). Factors affecting the farmers'decision on artificial insemination: a case study of diyarbakir province, turkey. applied ecology and environmental research, 17(1), 13891399.

Bachev, H., Ivanov, B., Toteva, D., \& Toteva, E. (2017). Agrarian sustainability in Bulgariaeconomic, social and ecological aspects. Bulgarian Journal of Agricultural Science, 23(4), 519525.

Bahar, L. D., Sudirman, I., \& Sirajuddin, S. N. (2017). The Farmers Willingness to Pay on Artificial Insemination in Bali Cattle. Entomology and Applied Science Letters, 4(2), 34-37.

Bansal, S. K., Bhagat, R. L., Sinha, A. K., Yadav, A. L., \& Phadke, N. L. (2019). Factors affecting conception rate in AI bred cattle under field conditions of Bihar. INDIAN JOURNAL OF ANIMAL SCIENCES, 89(1), 110-112.

BPS. (2013). Results of the agricultural cencus. Official statistics news no. 62/09/Th.XVI.2 September 2013. Jakarta: Indonesia.

Declaro-Ruedas, M. Y. A., \& Bais, L. S. (2019). Communication Modalities Used in the Delivery of Extension Programs to Small Scale Livestock Raisers in San Jose, Occidental Mindoro, Philippines. International Journal of Agricultural Extension, 7(1), 39-44.

Department of livestock and animal health, B. (2015). No Title. Indonesian Statistic.

Edwina, S., Maharani, E., Kusumawaty, Y., Yusri, J., \& Yusmini, Y. (2019). Perception of Farmers of Communal and Individual Stalls Towards the Role of Extension on Integrated Farming in Pelalawan District. Jurnal Penyuluhan, 15(2), 217-229.

Giampaoli, D., Ciambotti, M., \& Bontis, N. (2017). Knowledge management, problem solving and performance in top Italian firms. Journal of Knowledge Management.

Ingabire, M. C., Yonggong, L., Pesha, J. C., \& Hardi, A. (2018). Factors affecting adoption of artificial insemination technology by small dairy farmers in Rwanda: A case of Rwamagana District. Journal of Economics and Sustainable Development, 9, 46-53.

Ma'sum, M., Hubeis, A. V. S., Saleh, A., \& Saharjo, B. (2012). Persepsi peternak tentang penerapan inseminasi buatan di tiga sentra sapi potong di Indonesia. Jurnal Penyuluhan, 8(1).

Ma'sum, M., Hubeis, A. V. S., Saleh, A., \& Saharjo, B. (2013). Hubungan Antara Karakteristik Internal dan Eksternal Peternak Sapi Potong dan Adopsi Inovasi Inseminasi Buatan. Jurnal Penyuluhan, 9(1).

Mazumder, A., \& Hoque, M. J. (2018). Correlation of Different Characteristics of the Farmers in.

Minister of Agriculture Decree No. 2842/Kpts/LB.430/8/2012, B. (2012). Dokumen Negara. Indonesia.

Monintja, M. Y., Oley, F. S., Sondakh, B. F., \& Oroh, F. N. S. (2015). Analisis Keuntungan Peternak Sapi Peranakan Ongole (Po) Yang Menggunakan Inseminasi Buatan (Ib) Di Kecamatan Tompaso Barat. ZOOTEC, 35(2), 201-209.

Prawira, H. Y., \& Sutrisna, R. (2015). Potensi Pengembangan Peternakan Sapi Potong di Kecamatan Tanjung Bintang Kabupaten Lampung Selatan. Jurnal Ilmiah Peternakan Terpadu, 3(4).

Rathod, P., Chander, M., \& Sharma G, C. (2017). Adoption status of artificial insemination in Indian dairy sector: application of multinomial logit model. Journal of Applied Animal Research, 45(1), 442-446.

Setiawan, D. (2018). Artificial Insemination of Beef Cattle UPSUS SIWAB Program Based on the Calculation of Non-Return Rate, Service Per Conception and Calving Rate In The North Kayong Regency. The International Journal of Tropical Veterinary and Biomedical Research, 3(1), 711.

Sirajuddin, S. N., Sudirman, I., Bahar, L. D., Al Tawaha, A. R., \& Al Tawaha, A. R. (2018). Social economic factors that affect cattle farmer's willingness to pay for artificial insemination programs. Bulgarian Journal of Agricultural Science, 24(4), 574-580.

Sugiarto, M., Wakhidati, Y. N., Einstein, A., \& Saleh, D. M. (2019). The influence of Artificial Insemination (AI) cost to profitability of beef cattle farming in Banjarnegara District, Central Java Province, Indonesia. IOP Conference Series: Earth and Environmental Science, 247(1), 12046.

Wiseman, L., Sanderson, J., Zhang, A., \& Jakku, E. (2019). Farmers and their data: An examination of farmers' reluctance to share their data through the lens of the laws impacting smart farming. 
NJAS-Wageningen Journal of Life Sciences, 90, 100301.

Yunasaf, U. (2012). Peran Penyuluh dalam Proses Pembelajaran Peternak Sapi Perah di KSU Tandangsari Sumedang (The Role of Extension Agent in Learning Process Dairy Farmer in KSU Tandangsari Sumedang). Jurnal Ilmu Ternak Universitas Padjadjaran, 12(1). 